\title{
Multiple endocrine neoplasia type 1 knockout mice develop parathyroid, pancreatic, pituitary and adrenal tumours with hypercalcaemia, hypophosphataemia and hypercorticosteronaemia
}

\author{
Brian Harding*, Manuel C Lemos*, Anita A C Reed, Gerard V Walls, \\ Jeshmi Jeyabalan, Michael R Bowl, Hilda Tateossian", Nicky Sullivan², \\ Tertius Hough', William D Fraser ${ }^{3}$, Olaf Ansorge ${ }^{2}$, Michael T Cheeseman ${ }^{1}$ \\ and Rajesh V Thakker
}

\author{
Academic Endocrine Unit, Nuffield Department of Clinical Medicine, Oxford Centre for Diabetes, Endocrinology and Metabolism \\ (OCDEM), Churchill Hospital, University of Oxford, Headington, Oxford OX3 7LJ, UK \\ ${ }^{1}$ Mammalian Genetics Unit and Mary Lyon Centre, Medical Research Council, Harwell, Oxfordshire OX11 ORD, UK \\ ${ }^{2}$ Department of Neuropathology, John Radcliffe Hospital, Headington, Oxford OX3 9DU, UK \\ ${ }^{3}$ Unit of Clinical Biochemistry, School of Clinical Sciences, University of Liverpool, Liverpool L69 3GA, UK \\ (Correspondence should be addressed to R V Thakker; Email: rajesh.thakker@ndm.ox.ac.uk) \\ *(B Harding and M C Lemos contributed equally to this work)
}

\begin{abstract}
Multiple endocrine neoplasia type 1 (MEN1) is an autosomal dominant disorder characterized in man by parathyroid, pancreatic, pituitary and adrenal tumours. The MEN1 gene encodes a 610 -amino acid protein (menin) which is a tumour suppressor. To investigate the in vivo role of menin, we developed a mouse model, by deleting Men 1 exons 1 and 2 and investigated this for MEN1-associated tumours and serum abnormalities. Men $1^{+/-}$mice were viable and fertile, and $220 \mathrm{Men1}^{+/-}$and $94 \mathrm{Men}^{{ }^{+/+}}$mice were studied between the ages of 3 and 21 months. Survival in $M e n 1^{+/-}$mice was significantly lower than in $M e n 1^{+/+}$mice $(<68 \%$ vs $>85 \%, P<0.01)$. $M e n 1^{+/-}$mice developed, by 9 months of age, parathyroid hyperplasia, pancreatic tumours which were mostly insulinomas, by 12 months of age, pituitary tumours which were mostly prolactinomas, and by 15 months parathyroid adenomas and adrenal cortical tumours. Loss of heterozygosity and menin expression was demonstrated in the tumours, consistent with a tumour suppressor role for the Men1 gene. Men $1^{+/-}$mice with parathyroid neoplasms were hypercalcaemic and hypophosphataemic, with inappropriately normal serum parathyroid hormone concentrations. Pancreatic and pituitary tumours expressed chromogranin $A(\mathrm{CgA})$, somatostatin receptor type 2 and vascular endothelial growth factor-A. Serum CgA concentrations in $M e n 1^{+/-}$mice were not elevated. Adrenocortical tumours, which immunostained for 3- $\beta$-hydroxysteroid dehydrogenase, developed in seven Men $1^{+/-}$mice, but resulted in hypercorticosteronaemia in one out of the four mice that were investigated. Thus, these $M e n 1^{+/-}$mice are representative of MEN1 in man, and will help in investigating molecular mechanisms and treatments for endocrine tumours.
\end{abstract}

Endocrine-Related Cancer (2009) 16 1313-1327

\section{Introduction}

Multiple endocrine neoplasia type 1 (MEN1), in man, is characterised by the combined occurrence of tumours of parathyroids, pancreatic islets and anterior pituitary (Marx 2005, Thakker 2006). Some patients may also develop adrenal cortical tumours, carcinoid tumours, facial angiofibromas, collagenomas and lipomas. MEN1 is inherited as an autosomal dominant disorder with a high degree of penetrance, such that $>95 \%$ of patients develop clinical manifestations of the disorder by the 
fifth decade (Calender et al. 1995, Trump et al. 1996, Marx et al. 1998). Parathyroid tumours, which lead to hypercalcaemia, are the most common feature of MEN1 and occur in $\sim 95 \%$ of patients (Calender et al. 1995, Trump et al. 1996, Marx et al. 1998). Pancreatic islet cell tumours, which consist of gastrinomas, insulinomas, pancreatic polypeptidomas, glucagonomas and vasoactive intestinal polypeptidomas occur in $\sim 40 \%$ of patients; anterior pituitary tumours, which consist of prolactinomas, somatotrophinomas, corticotrophinomas or non-functioning adenomas, occur in $\sim 30 \%$ of patients; and adrenal cortical tumours, which are usually non-secreting but may occasionally be associated with hypercortisolaemia or hyperaldosteronism, may occur in 35\% of patients (Calender et al. 1995, Trump et al. 1996, Marx et al. 1998, Vierimaa et al. 2007).

The MEN1 gene, which is a tumour-suppressor gene located in human chromosome 11q13, consists of 10 exons (Fig. 1) that span approximately $>9 \mathrm{~kb}$ of genomic DNA and encodes a 610-amino acid protein referred to as menin (Chandrasekharappa et al. 1997, The European Consortium on MEN1 1997). The main transcript of the MENl gene is a $2.8 \mathrm{~kb}$ mRNA. However, at least six alternative transcripts, which utilise alternative exons 1 , have been reported with variations in their content of the $5^{\prime}$-untranslated region (Khodaei-O'Brien et al. 2000), and another rare variant that would result in an elongation of the reading frame by 15 bases at the exon 2 /intron 2 junction has also been reported (Chandrasekharappa \& Teh 2003). In order to study the in vivo role of menin, we embarked on generating a mouse model for MEN1 through homologous recombination (i.e. knockout) of the mouse Men 1 gene. During the course of our studies eight mouse models (four conventional and four conditional knockouts) for MEN1 have been reported (Table 1; Crabtree et al. 2001, 2003, Scacheri et al. 2001, Bertolino et al. 2003a, b, Libutti et al. 2003, Biondi et al. 2004, Loffler et al. 2007). Each one of these Men1 mouse models has been generated by disrupting different parts of the Menl gene and by different strategies, e.g. conventional or conditional knockout (Table 1). The resulting phenotypes in Menl ${ }^{+/-}$mice have been variable and ranged from embryonic lethality (Scacheri et al. 2001) to full viability and fertility into adult life with the development of a range of different MEN1-associated and nonMEN1-associated tumours, e.g. phaeochromocytomas, thyroid tumours and gonadal tumours (Table 1). The basis for these differences remain to be elucidated; however, it is interesting to note that in two of the conventional Men $1^{+/-}$models, exon 2 which contains the ATG translational start signal had not been deleted
(Crabtree et al. 2001, Bertolino et al. 2003a), and that in the other conventional Menl ${ }^{+/-}$model exon 1 and the alternative exons 1 remained intact (Table 1). This raises the possibility that there may be potentially other alternative partial transcripts that may be able to compensate for the absence of the full normal Menl transcript, and the situation may be analogous to that recently reported for the extracellular calcium-sensing receptor which has tissue-specific alternative spliced transcripts (Chang et al. 2008). Although, an important role for the alternative Menl transcripts is unlikely, as six out of the seven do not normally affect the coding region (Khodaei-O'Brien et al. 2000, Lemos \& Thakker 2008), we nevertheless decided to generate a targeting vector that lacked exons 1 and 2 , and a $>1.5 \mathrm{~kb}$ region of the $5^{\prime}$ sequence that contained the untranslated region (UTR), promoter and alternative exons 1 , and $\sim 1 \mathrm{~kb}$ of the $5^{\prime}$ region of intron 2 (Fig. 1).

\section{Materials and methods}

\section{Construction of the gene targeting vector and generation of mouse model for MEN1}

Genomic clones containing overlapping portions of the murine Menl gene were isolated, using PCR and Menl-specific primers, from a $129 / \mathrm{Sv}$ BAC library (Incyte Genomics, Inc., St Louis, MO, USA). A $13.5 \mathrm{~kb}$ ApaI fragment containing exons 1-2 and the adjacent $5^{\prime}$ region, and a $5.1 \mathrm{~kb} \mathrm{HpaI}$ fragment containing exons $3-10$ and the adjacent $3^{\prime}$ region were selected for generating the targeting construct. The $13.5 \mathrm{~kb} \mathrm{ApaI}$ fragment was digested with EcoRI to generate a $4.8 \mathrm{~kb}$ fragment that contained $1.9 \mathrm{~kb}$ of the UTR adjacent to the coding region as well as the promoter and alternative exons 1 ( $5^{\prime}$ homology arm), and the $5.1 \mathrm{~kb} \mathrm{HpaI}$ fragment was digested with HpaI and EcoRV to generate a $4.4 \mathrm{~kb}$ fragment that contained part of intron 2, exons 3-10 and the $3^{\prime}$ adjacent region ( $3^{\prime}$ homology arm; Fig. 1A). The targeting vector was constructed by ligating the $5^{\prime}$ arm into the EcoRI site and the $3^{\prime}$ arm into the SmaI site of the 38LoxPNeo vector (Incyte Genomics, Inc). The resulting targeting vector lacked a $3 \mathrm{~kb}$ sequence that comprised $1.9 \mathrm{~kb}$ of the $5^{\prime}$ sequence, exons $1-2$ (including the ATG initiation codon), and $\sim 1 \mathrm{~kb}$ of the $5^{\prime}$ region of intron 2 of the Menl gene; this $3 \mathrm{~kb}$ sequence was replaced by a $2.1 \mathrm{~kb}$ selectable phosphoglycerate kinase (PGK)-neomycin resistance (Neo) cassette that was flanked with LoxP sites, in the opposite transcriptional orientation to Menl (Fig. 1A). The 38LoxPNeo/Menl vector was linearised and electroporated into murine $129 / \mathrm{SvJ}$ embryonic stem (ES) cells. ES cells that had a correct homologous 
A
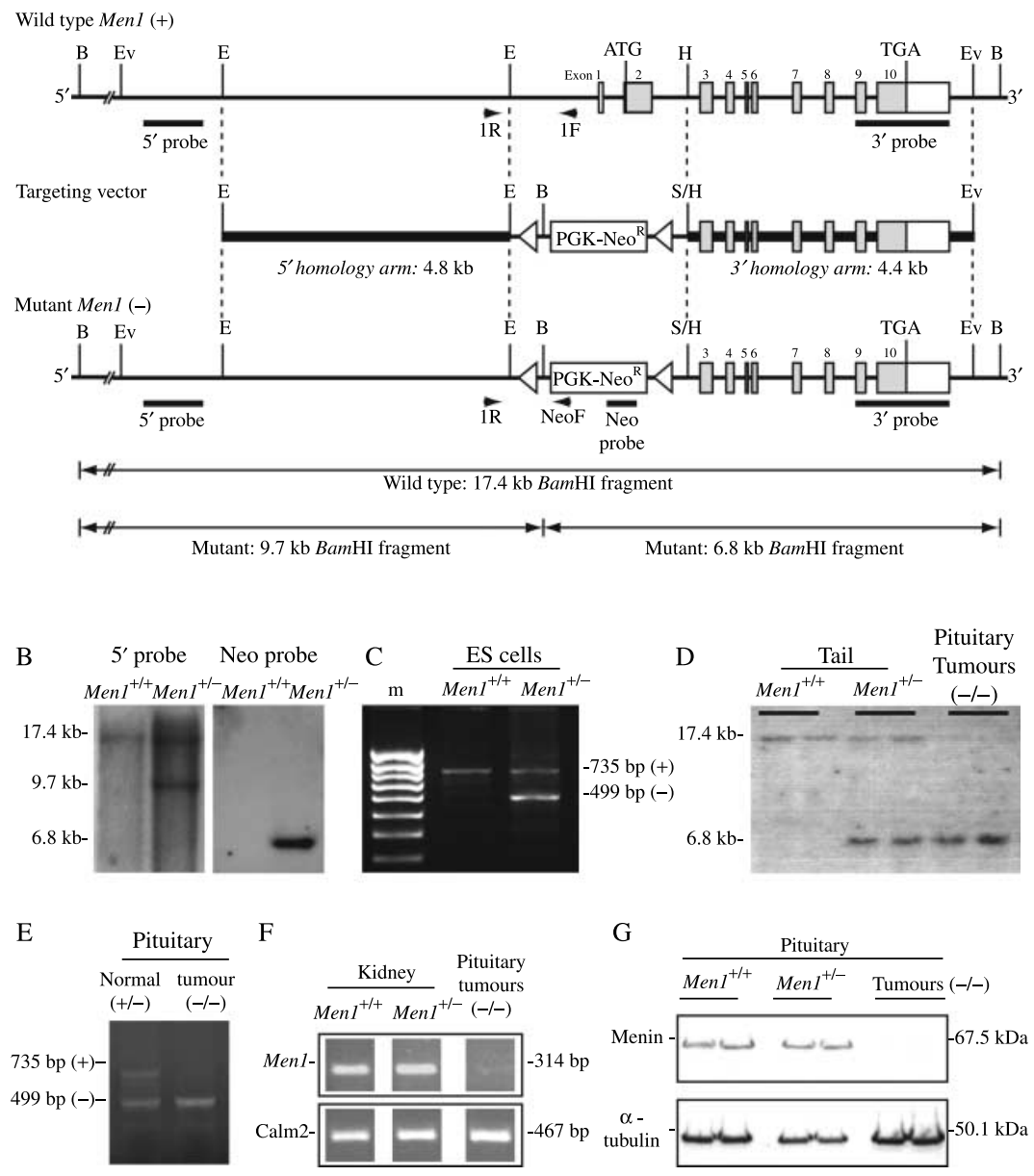

Figure 1 Targeted disruption of the Men1 gene. (A) Restriction maps of the Men1 gene representing the wild-type (+) and mutantrecombinant $(-)$ alleles. The exons are represented by boxes (filled boxes depict translated regions), and the locations of restriction enzymes sites (BamHI (B), EcoRV (Ev), EcoRI (E), Hpal (H) and Smal (S)) together with genomic fragments used as $5^{\prime}, 3^{\prime}$ and neocassette (Neo) probes for Southern blot analysis are shown. PCR primers (1R, $1 \mathrm{~F}$ and NeoF) were designed to facilitate detection of the wild-type $(+)$ and mutant $(-)$ alleles. Exons 1 and 2 together with $\sim 1.9 \mathrm{~kb}$ of the $5^{\prime}$ adjacent region and $\sim 1.0 \mathrm{~kb}$ of intron $2 \mathrm{were}$ disrupted by introduction of the neomycin transferase gene linked to the phosphoglycerate (PGK) promoter (PGK-Neo), in the opposite transcriptional orientation to Men1; the PGK-Neo cassette was flanked by LoxP recognition sequences (open triangles). (B) BamHI Southern blot analysis of genomic DNA extracted from untransfected ES cells (wild-type, Men $1^{+/+}$) and transfected with Men1 targeting construct $\left(M e n 1^{+1-}\right)$, using the $5^{\prime}$ or Neo probe. Hybridisation with the $5^{\prime}$ probe yielded a $17.4 \mathrm{~kb}$ band for the wild-type allele and a $9.7 \mathrm{~kb}$ band for the mutant allele, while hybridisation with the Neo probe yielded a $6.8 \mathrm{~kb}$ band for the mutant allele, and no signal from wild-type DNA. (C) Genotyping by PCR, utilising primers 1F, $1 \mathrm{R}$ and NeoF revealed the presence of the wild-type (735 bp) and mutant (499 bp) alleles from the targeted Men $1^{+/-}$ES cells, but only the 735 bp from the normal $\left(M e n 1^{+/+}\right.$) ES cells. (D) Southern blot analysis of genomic DNA extracted from mouse tails or pituitary tumours, digested with BamHI and hybridised with the $3^{\prime}$ probe. DNA from Men $1^{+/+}$mice showed the expected $17.4 \mathrm{~kb}$ band, and the Men $1^{+/-}$mice showed both the 17.4 and $6.8 \mathrm{~kb}$ bands; DNA from the pituitary tumours that developed in Men $1^{+/}$mice showed only the mutant $6.8 \mathrm{~kb}$ band, consistent with a loss of heterozygosity (LOH) in the tumour. (E) Genotyping by PCR utilising primers $1 \mathrm{R}, 1 \mathrm{~F}$ and NeoF revealed the presence of the wild-type (735 bp) and mutant (499 bp) alleles in the normal pituitary of Men $1^{+/-}$mice, but only the mutant (499 bp) allele from pituitary tumours of these mice, consistent with LOH in the tumours. (F) RT-PCR analysis of normal kidney extracts from $M e n 1^{+/+}$and Men $1^{+/-}$mice revealed the presence of a Men1 transcript, which was absent in pituitary tumours from Men $1^{+/-}$ mice. Control calmodulin 2 (Calm2) expression is shown. (G) Western blot analysis of normal pituitary extracts from Men1 ${ }^{+/+}$and $M e n 1^{+1-}$ mice revealed the expression of menin; however, extracts of pituitary tumours that developed in Men $1^{+/-}$mice revealed a loss of menin expression. Control immunoblotting for $\alpha$-tubulin is shown.

recombination were identified by Southern blot (Fig. 1B) and PCR analysis (Fig. 1C), and expanded for injection into blastocysts. Between five and seven ES cells were used for each injection into 3.5-day-old
C57BL/6 blastocysts that were then transferred to pseudo-pregnant female recipients. The resulting male chimaeras were bred with C57BL/6 females to obtain germline transmission of the targeted allele. 


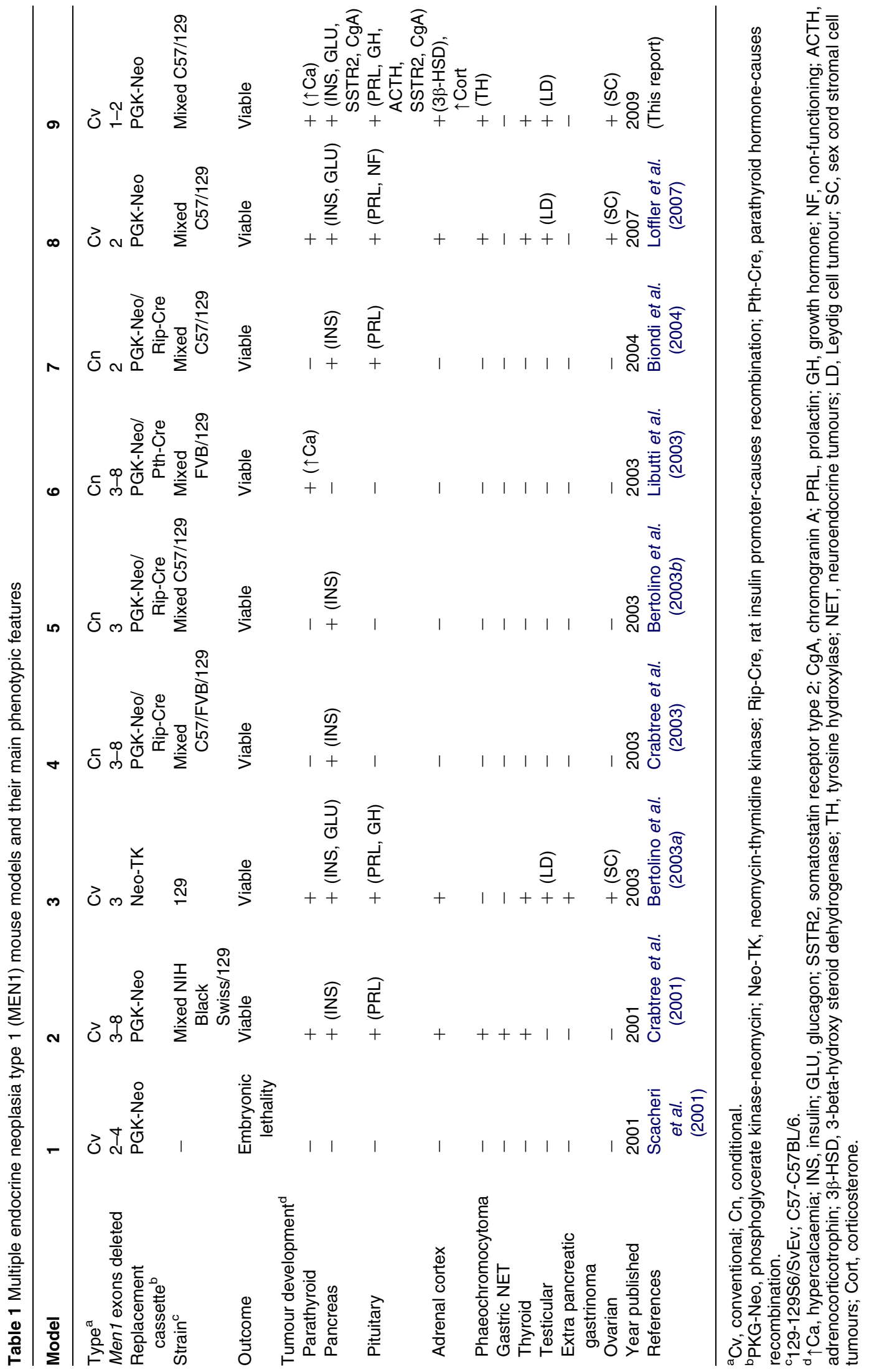




\section{Phenotype studies}

Mice were kept in accordance with UK Home Office welfare guidelines and project license restrictions. Mice were maintained on a mixed C57BL/6X 129S6/SvEv background and fed a standard diet (RM1 expanded diet, Special Diet Services Ltd, Witham, UK). Wild-type $\left(\right.$ Menl $\left.{ }^{+/+}\right)$and heterozygous $\left(\mathrm{Menl}^{+/-}\right)$mice were killed every 3 months, beginning at 3 months and continuing until 21 months, and a blood sample was immediately taken by cardiac puncture and the serum stored at $-20^{\circ} \mathrm{C}$.

\section{Genotype studies}

Genotypes were determined by Southern blot (Fig. 1D) and PCR (Fig. 1E) analysis, as previously described (Thakker et al. 1989, Pannett \& Thakker 2001). PCR analysis was performed using primers (1R (5'-CCA AAC TCC ATG TTC CAA TAT GAC AGC- $3^{\prime}$ ); $1 \mathrm{~F}$ (5'-CAC GAA GTC TGT AAT GAC CCT GTT TCC$\left.3^{\prime}\right)$; and NeoF (5'-CTC TCG TGG GAT CAT TGT TTT TCT C- $\left.3^{\prime}\right)$ ). Primers $1 \mathrm{R}$ and $1 \mathrm{~F}$ yielded a $735 \mathrm{bp}$ wild-type band and primers $1 \mathrm{R}$ and $\mathrm{NeoF}$ yielded a 499 bp band (Fig. 1C and E).

\section{Reverse transcriptase-PCR (RT-PCR) analysis}

RT-PCR, using total RNA extracted from Menl ${ }^{+/+}$ and $\mathrm{Men1^{+/- }}$ kidneys, as controls, and pituitary tumours obtained from Men1 ${ }^{+/-}$mice (Fig. 1F), was performed using either Menl-specific primers (forward $5^{\prime}$-GCT TCG TGG AGC ATT TCC T-3'; and reverse $5^{\prime}$-TCC AGT CCC TCT TCA GCT TC-3') or control calmodulin-2 primers (forward $5^{\prime}$-AT GGC TGA CCA ACT GAC TGA A-3'; and reverse $5^{\prime}$-C ATT CTG TAC AAT GTC TTC ACT T- $3^{\prime}$ ), as described (Nesbit et al. 2004).

\section{Western blot analysis}

Western blot analysis using total protein from normal pituitaries and pituitary tumours from $\mathrm{Menl} \mathrm{I}^{+/-}$mice was performed (Fig. 1G), as previously described (Nesbit et al. 2004).

\section{Histology and immunohistochemistry}

Tissues were fixed in neutral buffered $4 \%$ formalin, except the testes, which were fixed in Bouin's solution. Detailed histology was initially undertaken on the majority of mice from the older cohort after which progressively younger age groups were studied until a very low tumour occurrence had been identified, after which histology studies were performed on smaller numbers of mice from subsequently younger age groups. In mice $\leq 12$ months, survey sections of thyroid/parathyroids were obtained, and in mice $\geq 15$ months, serial sections were performed whenever possible. However, this approach often failed to locate the parathyroids because of their high occurrence at extra-thyroidal sites (Capen et al. 1996). For immunohistochemical analysis, commercially available antibodies were obtained (details available upon request) and used according to the manufacturer's instructions. The slides were counterstained with haematoxylin.

\section{Clinical chemistry}

Serum was analysed for calcium, phosphate, creatinine and albumin, as previously described (Hough et al. 2002). Total serum calcium (Ca) was adjusted (ACa) for albumin (Alb) using the formula: $\mathrm{ACa}=\mathrm{Ca}(\mathrm{mmol} / \mathrm{l})-$ $((\mathrm{Alb}(\mathrm{g} / \mathrm{l})-30) \times 0.017)$. Serum parathyroid hormone $(\mathrm{PTH})$ concentration was measured using an ELISAspecific for mouse intact PTH (Immutopics, San Clemente, CA, USA). Serum chromogranin A (CgA) was measured using a direct ELISA (Dako, Glostrup, Denmark). Corticosterone was measured using an enzyme immunoassay (IDS Ltd, Boldon, Tyne \& Wear, UK) following prior dilution of the mouse sera.

\section{Statistical analysis}

Comparisons of tumour occurrence were made by appropriate use of Fisher's exact test and $2 \times 2$ contingency tables. Two-tailed $P$ values were calculated and statistical significance set at $P<0.05$. A two-tailed Student's $t$-test and $\chi^{2}$ test were appropriately used to analyse the results of serum measurements. Kaplan-Meier analysis was performed and a two-tailed log rank test used.

\section{Results}

\section{Generation of the $\mathrm{Men1}^{+/-}$mice}

Menl ${ }^{+/-}$mice were generated by targeted deletion of

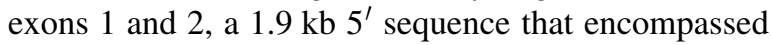
the UTR, promoter and alternative exons 1 , and an $\sim 1 \mathrm{~kb}$ sequence of the $5^{\prime}$ region of intron 2 ; these sequences were replaced by a neomycin resistance gene in ES cells (Fig. 1A-C). PCR analysis using primers 1F, $1 \mathrm{R}$ and $\mathrm{NeoF}$ showed that ES cells transfected with the targeting construct had the wildtype (735 bp) and mutant (499 bp) bands (Fig. 1C). Similarly, BamHI-digested DNA from the transfected ES cells used for Southern blot analysis that utilised a $5^{\prime}$ probe, which consisted of a $1.4 \mathrm{~kb}$ XbaI-EcoRI 
fragment, yielded a wild-type allele of $17.4 \mathrm{~kb}$ and a mutant allele of $9.7 \mathrm{~kb}$ (Fig. 1B). The additional use of a $0.6 \mathrm{~kb}$ PCR product from the neomycin resistance gene as a probe yielded a hybridisation signal of $6.8 \mathrm{~kb}$, thereby confirming the corrected incorporation of the PGK-Neo cassette in transfected ES cells. ES cell clones with a correct homologous recombination of the construct were injected into blastocysts, which were then transferred to pseudo-pregnant female mice. The resulting male chimaeras were bred with C57BL/6 females to obtain germline transmission, which was confirmed by Southern blot analysis of genomic DNA (Fig. 1D). Men1 ${ }^{+/-}$mice were viable and fertile but $\mathrm{Men1^{-1- }}$ mice were embryonically lethal (Lemos et al. 2007).

\section{Development of tumours and pathological analysis}

Menl ${ }^{+/-}$mice and their wild-type $\left(M e n 1^{+/+}\right)$ littermates were studied for the development of tumours at 3 monthly intervals over a 21 month period, commencing at 3 months of age. A total of 314 mice (94 control Menl ${ }^{+/+}$(40 males and 54 females) and $220 \mathrm{Menl}^{+/-}$(90 males and 130 females)) were studied. Premature unexpected death occurred in 85 mice $\left(14 \mathrm{Menl}^{+/+}(5\right.$ males and 9 females) and 71 Menl ${ }^{+/-}$(13 males and 58 females)) and tumour development was therefore studied in the remaining 229 live mice ( 80 control Menl ${ }^{+/+}$(35 males and 45 females) and $149 \mathrm{MenI}^{+/-}$mice $(77$ males and 72 females)). The weights of the MenI ${ }^{+/+}$and MenI ${ }^{+/-}$ mice, at the time of necropsy were not significantly different (data not shown). In total, 211 tumours were identified from $71 \mathrm{Menl}{ }^{+/-}$mice (37 males and 34 females). Tumours were found to have loss of heterozygosity $(\mathrm{LOH})$ and loss of menin expression (Figs 1D-G, and 2; see below).

Overall, only $5 \%$ of $\mathrm{MenI}{ }^{+/-}$mice $\leq 9$ months of age developed tumours, whereas $84 \%$ of the $M e n 1^{+/-}$ mice aged $\geq 12$ months developed tumours, consistent with an age-related penetrance for the condition (Fig. 3A). The higher occurrence of tumours in Menl ${ }^{+/-}$mice aged $\geq 12$ months was coincident with the onset of an increased mortality in these mice (Fig. 3B); the survival in the Menl ${ }^{+/-}$mice was significantly lower at $<68 \%$ while that in the Menl $1^{+1+}$ mice was $>85 \%(P<0.01$, Fig. 3B $)$. The $\geq 12$ months old $\mathrm{Menl}^{+/-}$mice developed tumours of the parathyroid, pancreatic islet, anterior pituitary, adrenal cortex, thyroid, testis and ovary (Fig. 3C). In addition, parathyroid and pancreatic islet cell tumours occurred in $>25 \%$ of $\mathrm{Menl}^{+/-}$mice, pancreatic islet tumours and anterior pituitary tumours occurred in $>15 \%$ of $\mathrm{Menl}^{+/-}$mice, anterior pituitary and parathyroid tumours were found in $\sim 1 \%$ of $\mathrm{Menl}^{+/-}$mice; and $6 \%$ of $\mathrm{Menl}^{+/-}$mice were found to have parathyroid, pancreatic islet cell and anterior pituitary tumours (Fig. 3D). The occurrence of parathyroid and pancreatic islet cell tumours was not significantly different in male and female MenI ${ }^{+/-}$mice, but the occurrence of anterior pituitary and adrenal cortical tumours showed significant gender differences (Fig. 3E). Thus, anterior pituitary tumours occurred more frequently in female Menl ${ }^{+/-}$mice, while adrenal cortical tumours occurred solely in male MenI $1^{+/-}$mice (Fig. 3E). Detailed analysis of the tumours in the Menl ${ }^{+/-}$mice revealed the following.

The parathyroid abnormalities consisted of adenomas or focal hyperplasia. The foci of hyperplasia that were characterised by clusters of pale atypical hypertrophic cells that did not compress the surrounding tissue or enlarge the parathyroid (Fig. 2A), were observed in $\mathrm{Menl}{ }^{+/-}$mice aged $\geq 9$ months. These parathyroid abnormalities are equivalent to those previously reported as focal dysplasia (Crabtree et al. 2001, Bertolino et al. 2003a) or hyperplasia (Loffler et al. 2007). The adenomas (Fig. 2B and C) that either had solid or papillary patterns with compression of adjacent normal tissue at the margin, occurred in $\mathrm{MenI}^{+/-}$mice aged $\geq 15$ months. The Menl ${ }^{+/-}$ mice with parathyroid hyperplasia had a significantly lower mean age (mean \pm s.D. $=16.95 \pm 4.05$ months) than those with adenomas $(19.88 \pm 2.23$ months, $P=0.02$ ). Both parathyroid hyperplasia and adenomas in man, cause primary hyperparathyroidism (Eastell et al. 2009) and are found in patients with MEN1 (Calender et al. 1995, Trump et al. 1996). The clinical and serum biochemical features of primary hyperparathyroidism, in man, arising from these two types of parathyroid proliferative abnormalities are indistinguishable, and the data from the Men1 ${ }^{+/-}$mice with these parathyroid abnormalities were therefore pooled for further analysis (see below).

Investigation of the pancreatic islets, stomach and proximal duodenum revealed abnormalities only of the pancreatic islets. These consisted of islet cell hyperplasia and adenomas; there was a continuum in islet size between hyperplasia and adenoma, and an islet with a width greater than one $\times 100$ objective field was chosen as an arbitrary cut-off to designate an adenoma. The islet cell hyperplasia occurred in $\mathrm{Men1^{+/- }}$ mice aged $\geq 6$ months while the earliest islet cell adenoma occurred in MenI ${ }^{+/-}$mice aged 9 months. Moreover, $\sim 60 \%$ of $\mathrm{MenI}{ }^{+/-}$mice aged $\geq 12$ months were found to have islet cell adenomas. The majority of 

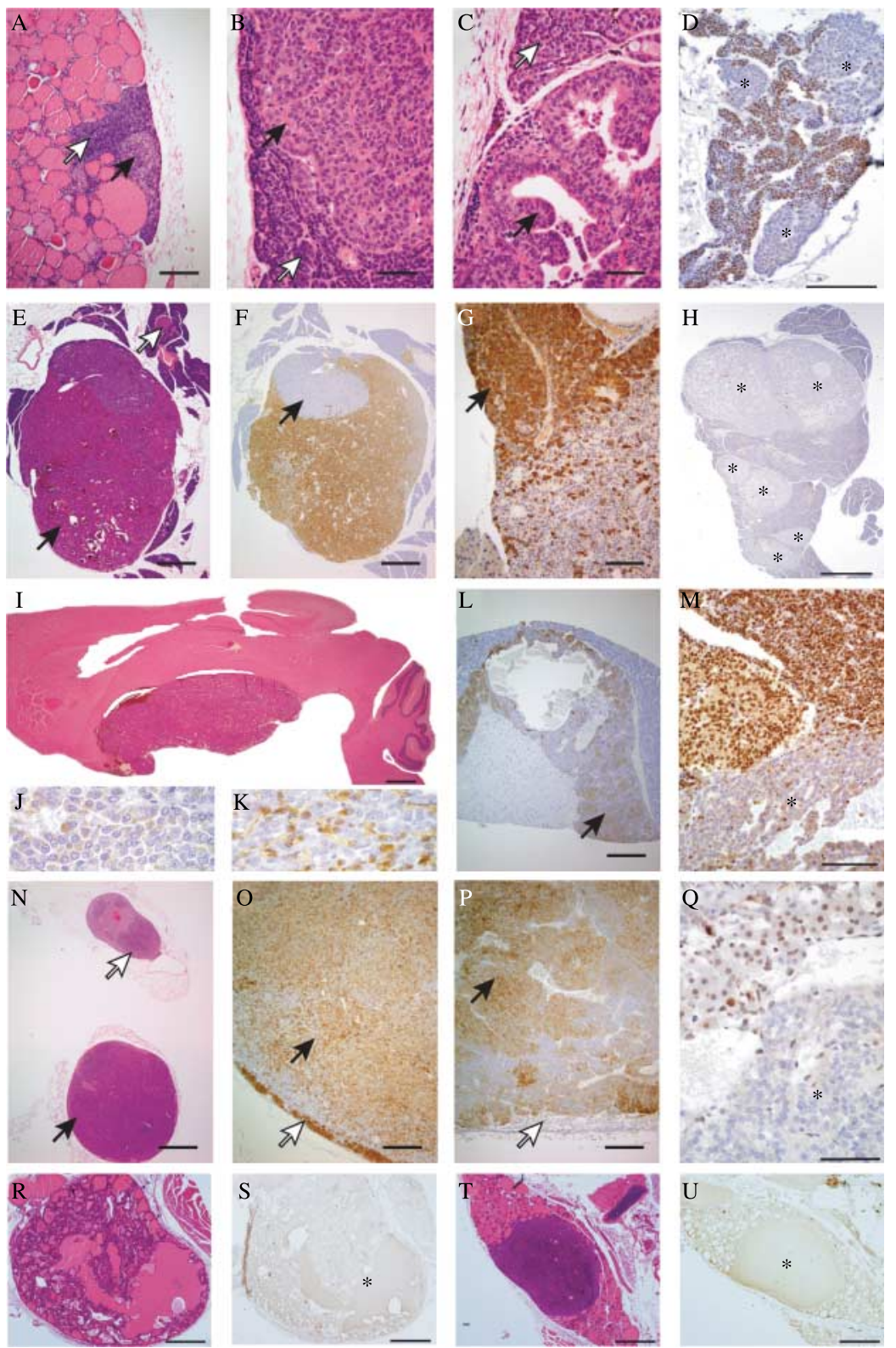

Figure 2 Proliferative endocrine lesions in Men1 $1^{+/-}$mice. (A-D) Parathyroids, $(\mathrm{E}-\mathrm{H})$ pancreas islets, (I-M) pituitary, $(\mathrm{N}-\mathrm{Q})$ adrenals and $(\mathrm{R}-\mathrm{U})$ thyroids. (A) Nodular parathyroid hyperplasia (black arrow), normal parathyroid (white arrow); (B) parathyroid adenoma (black arrow) and normal parathyroid (white arrow); (C) papillary parathyroid adenoma (black arrow) and adjacent parathyroid (white arrow); (D) parathyroid adenomas showing loss of menin expression (indicated by asterisks); (E) pancreatic islet tumour (black arrow) and a normal sized islet (white arrow); (F) insulin staining of the same tumour showing a non-staining peripheral nodule (black arrow); (G) glucagon-positive nodule of the same tumour (black arrow); (H) multinodular neoplasia of pancreas with loss of menin expression (asterisks); (I) pituitary macroadenoma compressing the overlying cerebrum; $(\mathrm{J})$ anterior pituitary macroadenoma containing prolactin; $(\mathrm{K})$ anterior pituitary macroadenoma containing $\mathrm{GH}$; (L) cystic ACTH containing pars intermedia tumour (arrow); (M) nuclear menin expression was lost in the pituitary adenoma cells, but preserved in adjacent non-neoplastic pituitary cells; (N) unilateral adrenal cortex adenoma (black arrow) and contralateral adrenal cortex hyperplasia (white arrow); (O) this adrenocortical tumour immunostained for $3 \beta$-HSD (black arrow) and has compressed residual cortex at the margin (white arrow); (P) phaeochromocytoma showing immunostaining for tyrosine hydroxylase (TH) (black arrow) with compressed cortex unstained with $\mathrm{TH}$ at the margin (white arrow); (Q) loss of menin expression in adrenal adenoma (asterisk); (R) thyroid follicular adenoma; (S) serial section showing loss of menin expression in the follicular adenoma (asterisk); (T) thyroid C-cell adenoma; (U) serial section showing loss of menin expression in the C-cell adenoma (asterisk). Scale bars $=1000 \mu \mathrm{m}(\mathrm{N}), 500 \mu \mathrm{m}(\mathrm{E}, \mathrm{F}, \mathrm{H}, \mathrm{I}$ and $\mathrm{R}-\mathrm{U}), 200 \mu \mathrm{m}(\mathrm{A}, \mathrm{L}, \mathrm{O}$ and $\mathrm{P}), 100 \mu \mathrm{m}$ $(D, G$ and $M), 50 \mu \mathrm{m}(B, C$ and $Q)$. 

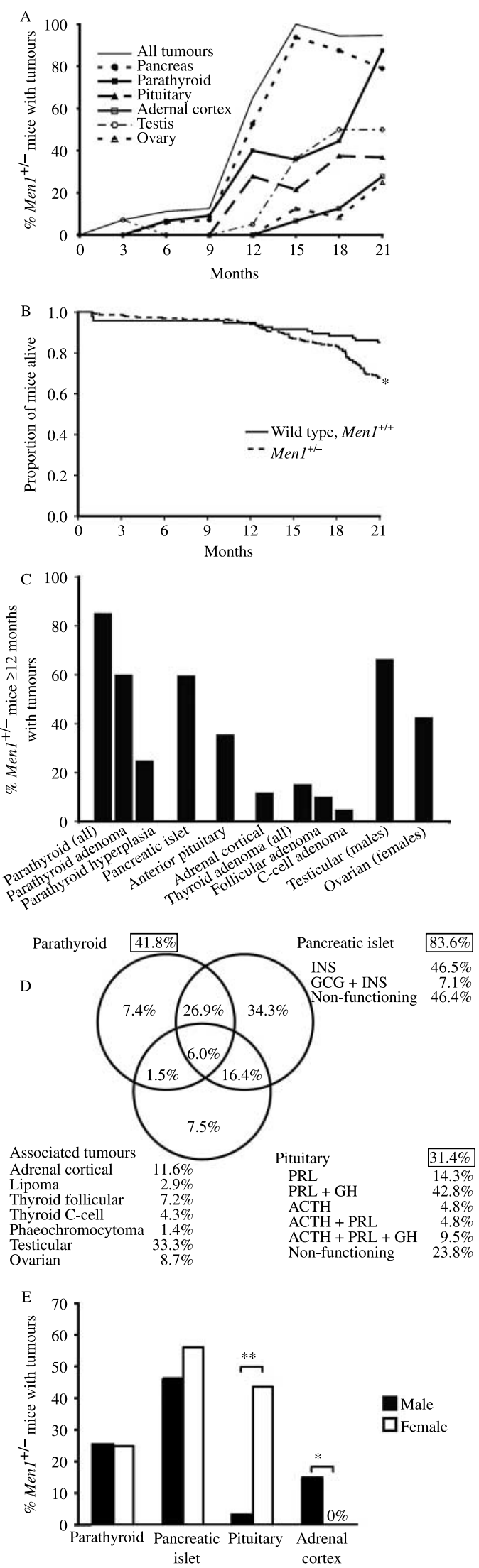

these islet cell adenomas contained insulin (Fig. 2E and $\mathrm{F}$ ), but $\sim 5 \%$ contained both insulin and glucagon (Fig. 2F and G). Forty percent of these pancreatic islet cell adenomas were also immunostained for pancreatic polypeptide and gastrin, and this revealed an absence of these peptides. Moreover, gastrin containing cells were not detected in the pancreatic islets of Menl ${ }^{+/+}$ or $M e n 1^{+/-}$mice (data not shown), and as duodenal gastrinomas are often found in MEN1 patients (Gibril et al. 2004), a detailed analysis of the stomach and proximal duodenum from $36 \mathrm{MenI}^{+/-}$mice aged 18-21 months was undertaken. This did not reveal the occurrence of any gastric or proximal duodenal neuroendocrine tumours.

Pituitary proliferative changes, which consisted of focal hyperplasia without compression or gland enlargement, occurred in $\mathrm{Menl}^{+/+}$and $\mathrm{Men1} \mathrm{I}^{+/-}$ mice aged $\geq 6$ months but only the Menl ${ }^{+/-}$mice

Figure 3 Tumour occurrence in Men1 ${ }^{+/-}$mice with tumours. (A) Percentage of $\mathrm{Men} 1^{+/-}$mice at different ages with tumours. The numbers of Men1 $1^{+/-}$mice studied at 3, 6, 9, 12, 15, 18 and 21 months of age were 20, 20, 21, 23, 22, 24 and 19, respectively. The results for the testicular and ovarian tumours are shown as a percentage of the combined total of male and female Men1 $1^{+/-}$mice. (B) Kaplan-Meier analysis revealed that survival among the Men $1^{+/-}$mice (149 out of 220 , i.e. $<68 \%$ ) was significantly lower than that in Men1 $1^{+/+}$mice (80 out of 94 , i.e. $>85 \%)\left({ }^{\star} P<0.01\right.$, log rank test). Survival in the Men1 ${ }^{+/+}$ and Men $1^{+/-}$mice was similar up to the age of 12 months, after which survival in the Men $1^{+/-}$mice began to decrease; this was coincident with the higher frequency of tumour development in the $M e n 1^{+/-}$mice that were $\geq 12$ months of age (Fig. $3 A$ and $B$ ). (C) Tumour development in Men $1^{+/-}$mice $\geq 12$ months age, revealed that $>85 \%$ had parathyroid proliferative abnormalities, which consisted of hyperplasia $(\sim 60 \%)$ and adenomas ( $>25 \%$ ); $>60 \%$ had pancreatic islet cell tumours, $>35 \%$ had anterior pituitary tumours, $>10 \%$ had adrenal cortical tumours, and $>15 \%$ had thyroid tumours which consisted of follicular adenomas $(>10 \%)$ and C-cell adenomas (>5\%). Two Men $1^{+/-}$ mice had lipomas, and one had a phaeochromocytoma. Testicular tumours developed in $>65 \%$ of male $\mathrm{Men}^{+/-}$mice, and ovarian tumours occurred in $>40 \%$ of $M e n 1^{+1-}$ female mice.

(D) Schematic representation of 211 tumours that were found in $71 \mathrm{Men}^{+/-}$mice. The proportions of $\mathrm{Men} 1^{+/-}$mice in which parathyroid, pancreatic or pituitary tumours occurred are shown in the respective boxes. For example, $41.8 \%$ of the Men $1^{+/-}$ mice had parathyroid hyperplasia or adenomas. The Venn diagram indicates the proportion of $M e n 1^{+1-}$ mice with each combination of tumours. For example, $26.9 \%$ of $M e n 1^{+/-}$mice had both a parathyroid and pancreatic tumour, whereas $34.3 \%$ of the $M e n 1^{+/-}$mice had a pancreatic tumour only. A similar analysis on the Men $1^{+/-}$mice aged $\geq 12$ months revealed that $>85 \%$ had parathyroid abnormalities, $>60 \%$ had pancreatic islet cell tumours, and $>35 \%$ had pituitary tumours. In addition, $>60 \%$ had combined parathyroid and pancreatic,

$>25 \%$ had pancreatic and pituitary tumours; and $\sim 10 \%$ had combined parathyroid, pancreatic islet cell and pituitary tumours; whilst none had combined parathyroid and pituitary tumours. The hormones contained within each of these tumours are indicated: INS, insulin; GCG, glucagon; PRL, prolactin; GH, growth hormone and ACTH, adrenocorticotrophin.

(E) Percentage of $M e n 1^{+/-}$male and female mice with tumours. $P$ values, ${ }^{*}<0.001,{ }^{* *}<0.0001$. 
developed tumours. Some pituitary macroadenomas were large enough to compress the overlying hypothalamus (Fig. 2I). The majority $(\sim 90 \%)$ of the pituitary tumours, originated from the pars distalis, and contained both prolactin and $\mathrm{GH}$, while the remainder $(\sim 10 \%)$ originated from the pars intermedia and contained ACTH (Fig. 2I-L); $>10 \%$ of Men1 ${ }^{+/-}$mice had both pars distalis and pars intermedia tumours. These pituitary tumours in the $M e n 1^{+/-}$mice which involved the pars distalis or pars intermedia are equivalent to the anterior pituitary tumours that arise in MEN1 patients. Pituitary tumours involving the pars nervosa, which is equivalent to the posterior pituitary (neurohypophysis) in man, were not found in the $\mathrm{MenI}^{+/-}$mice. More than $75 \%$ of the pituitary tumours contained prolactin, $\mathrm{GH}$ and $\mathrm{ACTH}$, and the remainder were considered to be nonfunctioning tumours.

Age-related incidental adrenal hyperplastic conditions consisting of cortical or subcapsular hyperplasia, and accessory adrenocortical nodules (Nyska \& Maronpot 1999) occurred in MenI ${ }^{+/+}$and MenI ${ }^{+/-}$ mice aged $\geq 6$ months, but only $M e n 1^{+/-}$mice developed adrenal tumours, seven of which consisted of cortical adenomas (Fig. 2N) that immunostained for

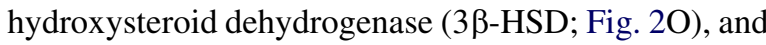
one was an adrenal medullary tumour, which immunostained for tyrosine hydroxylase (Fig. 2P) and hence was consistent with a phaeochromocytoma.

Gonadal tumours, which are not associated with MEN1 in man, consisted of either Leydig cell tumours or teratoma in $\mathrm{Men1^{+/- }}$ male mice, or tubulostromal or sex cord/stromal cell tumours in Men $1^{+/-}$female mice (data not shown). Approximately $45 \%$ of $\mathrm{MenI}^{+/-}$ males $\geq 9$ months of age had Leydig cell hyperplasia, but this was not observed in any of the Men $1^{+/+}$mice. Unilateral or bilateral Leydig cell tumours, which developed in $\mathrm{MenI}^{+/-}$male mice aged $\geq 12$ months, occurred in $\sim 60 \%$ of $\mathrm{MenI}^{+/-}$mice and were sometimes associated with Leydig cell hyperplasia in the contralateral testis. Moreover, these tumours were malignant with invasion of the capsule in $\sim 10 \%$ of mice. Only one $\mathrm{MenI}^{+/-}$male mouse, aged 3 months, had a testicular teratoma. In six MenI ${ }^{+/-}$female mice aged $>15$ months, there were seven ovarian tumours; three were granulosa cell tumours, two were dysgerminomas and there were single cases of luteoma and tubulostromal tumours. One female $\mathrm{Men1^{+/- }}$ mouse had a unilateral granulosa cell tumour and a contralateral dysgerminoma.

Macroscopic abnormalities were not detected in any of the MenI ${ }^{+/+}$littermates below 18 months of age. In those $\mathrm{Menl}^{+/+}$control mice over the age of
18 months, macroscopic lesions were observed in five mice. Histology revealed that these lesions consisted of: a mesenteric anaplastic spindle cell sarcoma; a lung adenoma; a focus of mesenteric fat necrosis; and two mice had cystic endometrial hyperplasia of the uterus and ovarian cysts. Men $1^{+/+}$mice had common agerelated pituitary and adrenal hyperplasia, but importantly, none of the MenI ${ }^{+/+}$control mice, including those at 21 months of age, were found to have macroscopic or microscopic tumours of the pancreas, pituitary, parathyroids, adrenals, thyroids or gonads, thereby indicating that the development of tumours in Menl ${ }^{+/-}$mice was not due to aging or the background of the mouse strain, but instead specific to loss of functioning Menl alleles and menin expression.

\section{LOH and absence of menin expression in tumours}

Tumour development in Men1 ${ }^{+/-}$mice was shown by Southern blot (Fig. 1D), PCR (Fig. 1E), RT-PCR (Fig. 1F), and western blot (Fig. 1G) analyses, to be associated with $\mathrm{LOH}$ in which there was a loss of the wild-type Men 1 allele. LOH was detected in $100 \%$ of anterior pituitary tumours $(n=20), 83 \%$ of pancreatic islet cell tumours $(n=12)$ and in $67 \%$ of adrenal cortical tumours $(n=6)$. In addition, loss of menin expression was shown by immunostaining to have occurred in parathyroid, pancreatic islet cell, anterior pituitary, adrenal cortical, thyroid (Fig. 2D, H, M, Q, S and $\mathrm{U}$ ) and testicular tumours (data not shown). These results demonstrate that tumour development in the Menl ${ }^{+/-}$mice is not a sporadic event in this strain, but instead it is specific and dependent on $\mathrm{LOH}$ of the wildtype Menl allele and a loss of menin expression. The loss of menin expression in the thyroid follicular and C-cell adenomas is of particular interest (Fig. 2R-U). Thyroid tumours consisting of adenomas, colloid goitres and carcinomas have been reported to occur in 25\% of patients with MEN1 (Thakker 2006). However, the prevalence of thyroid disorders in the general population is high, and it has been suggested that the association of thyroid abnormalities in patients with MEN1 may be incidental and not specific for MEN1. Our results showing loss of menin expression in two types of thyroid tumours (Fig. 2R-U) that occurred in $\mathrm{MenI}^{+/-}$mice, indicate that their development is specific to loss of Menl expression; this suggests the possibility that the occurrence of thyroid tumours may be part of the MEN1 syndrome in man and indicates that similar studies in human thyroid tumours from MEN1 patients are warranted. 


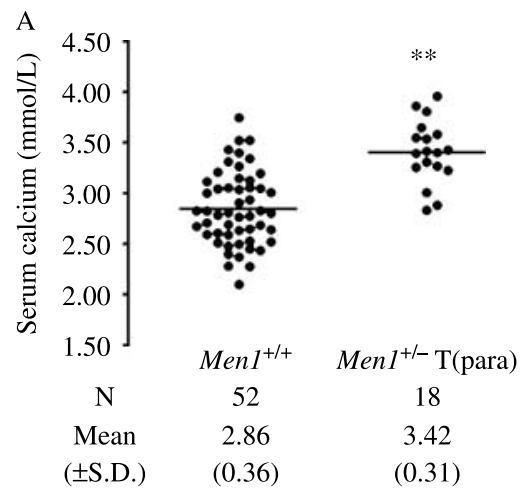

$\mathrm{B}$
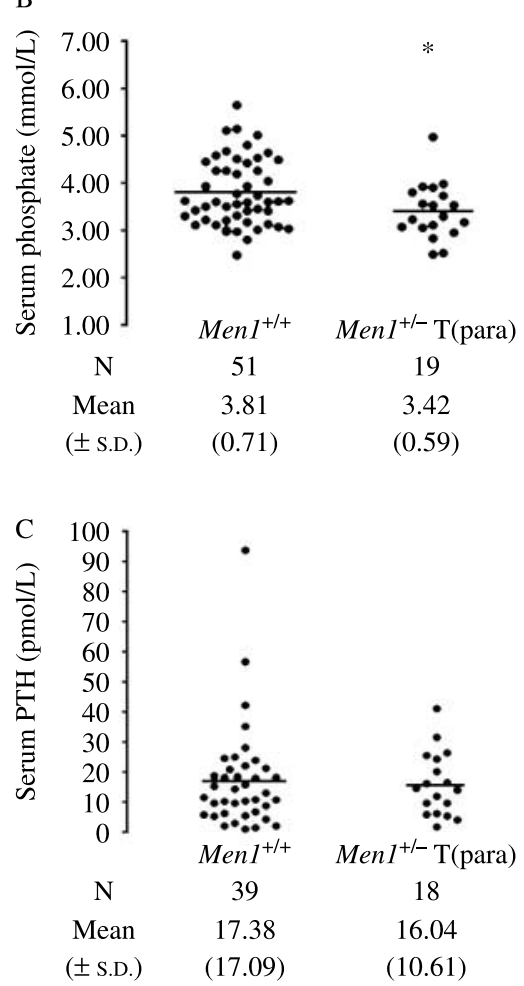

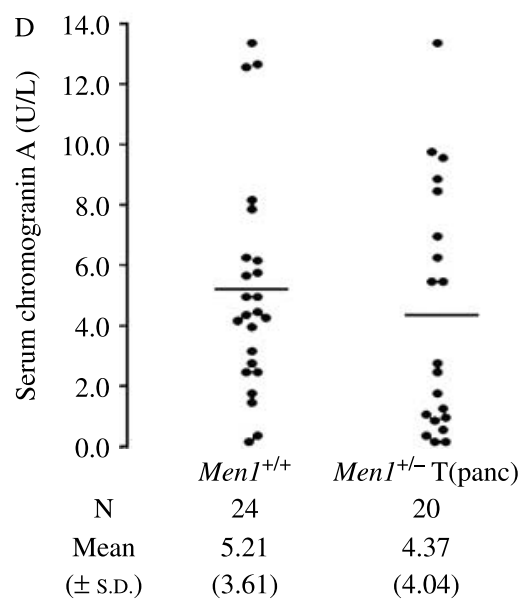

\section{Serum analysis}

Serum total calcium (adjusted for albumin), phosphate, $\mathrm{PTH}$, creatinine and $\mathrm{CgA}$ in $\mathrm{Men1^{+/- }}$ mice with tumours, and also control Menl ${ }^{+/+}$mice were measured (Fig. 4). The serum creatinine and albumin were similar in $\mathrm{Men1^{+/+ }}$ male and female mice, and in $\mathrm{MenI}^{+/-}$male and female mice with and without tumours (data not shown). In addition, these values were similar in the different age groups (data not shown) and total and adjusted serum calcium (ACa) in the Menl ${ }^{+/+}$mice was also similar in both sexes and in the different age groups (data not shown). The data from both sexes and the different age groups were therefore pooled for analysis.

Menl ${ }^{+/-}$mice with parathyroid proliferative abnormalities were found to have significant hypercalcaemia and hypophosphataemia when compared to MenI $^{+/+}$mice, consistent with PTH overactivity (Fig. 4A and B). However, the serum PTH concentrations in these $\mathrm{Men} \mathrm{I}^{+/-}$mice were similar to that in the normocalcaemic Menl ${ }^{+/+}$mice (Fig. 4C). These findings of serum PTH concentrations within the normal range, in association with hypercalcaemia are indicative of inappropriate elevations in serum PTH concentrations for the prevailing $\mathrm{ACa}$ and are consistent with primary hyperparathyroidism (Eastell et al. 2009). Men1 ${ }^{+/-}$mice $(n=60)$ in whom parathyroid abnormalities were not detected by histology, were also found to have significant hypercalcaemia (mean $\mathrm{ACa} \pm$ s.D. $=3.31 \pm 0.30 \mathrm{mmol} / \mathrm{l}$ ) when compared to Menl ${ }^{+/+}$mice $(2.86 \pm 0.36 \mathrm{mmol} / 1$, $n=52, \quad P<0.01)$, but not hypophosphataemia $\left(\right.$ Menl $^{+/-}$mean phosphate \pm s.D. $=3.71 \pm 0.82 \mathrm{mmol} / \mathrm{l}$ versus $\left.\mathrm{Menl}^{+/+} 3.81 \pm 0.71 \mathrm{mmol} / \mathrm{l}\right)$. These $M e n 1^{+/-}$ mice likely represent a heterogeneous group in which some have no parathyroid abnormalities, while others have parathyroid adenomas or hyperplasia that were not detected by histology owing to the sampling

Figure 4 Serum calcium, phosphate, PTH and chromogranin A concentrations. (A) Serum calcium adjusted for albumin, (B) serum phosphate, and (C) serum PTH concentrations in Men $1^{+/+}$and Men1 $1^{+/-}$mice with parathyroid hyperplasia or adenomas (Men $1^{+1-} \mathrm{T}$ (para)). (D) Serum chromogranin A concentrations in Men1 $1^{+/+}$and Men1 $1^{+/-}$mice with histologically proven pancreatic tumours (Men1 ${ }^{+/-} \mathrm{T}$ (panc)). The results for individual mice are shown. The bars show the mean for each group. $P$ values, ${ }^{*}<0.05,{ }^{* *}<0.001$.

The Men $1^{+/}$T(para) mice were significantly hypercalcaemic and hypophosphataemic when compared to the Men $1^{+/+}$mice. The serum PTH concentrations were similar in both groups, but the occurrence of a serum PTH concentration in the normal range in association with hypercalcaemia is considered to be inappropriate, and consistent with primary hyperparathyroidism (Eastell et al. 2009). 
difficulties outlined above. The mean $( \pm$ s.D. $)$ serum PTH in these $M e n 1^{+/-}$mice $(17.61 \pm 14.09 \mathrm{pmol} / \mathrm{l}$, $n=59$ ) without parathyroid proliferative abnormalities was not significantly different from that in $\mathrm{Men1} \mathrm{I}^{+/+}$ mice $(17.38 \pm 17.09 \mathrm{pmol} / \mathrm{l}, n=39)$.

The serum CgA was not significantly different in $M e n 1^{+/-}$mice with pancreatic islet cell tumours when compared with $\mathrm{Men} \mathrm{I}^{+/+}$mice (Fig. 4D). In addition, Menl ${ }^{+/-}$mice $(n=40)$ without pancreatic islet cell tumours when compared to Menl ${ }^{+/+}$mice $(n=24)$ had similar mean serum $\mathrm{CgA}$ concentrations $\left(\right.$ Men $^{+/-}$mean \pm s.D., $4.42 \pm 2.93$ U/1 versus Menl $\left.{ }^{+/+}, 5.21 \pm 3.61 \mathrm{U} / \mathrm{l}\right)$. These findings indicate that serum $\mathrm{CgA}$ is unlikely to be a useful marker for pancreatic neuroendocrine tumours in $\mathrm{Menl} \mathrm{I}^{+/-}$mice.

The adrenal cortical tumours, which occurred in the Menl ${ }^{+/-}$male mice, showed immunostaining for $3 \beta$-HSD (Fig. 2O). Serum corticosterone which is the main glucocorticoid hormone in rodents and precursor of aldosterone (Malisch et al. 2009) was measured. The mean serum corticosterone concentrations in the MenI ${ }^{+/-}$male mice with adrenal cortical hyperplasia $(53 \pm 9 \mathrm{nmol} / \mathrm{l}, n=14)$ were similar to those Men1 ${ }^{+/-}$ male mice without adrenal cortical abnormalities $(74 \pm 14 \mathrm{nmol} / \mathrm{l}, \quad n=54)$ and $M e n 1^{+/+}$male mice $(56 \pm 13 \mathrm{nmol} / \mathrm{l}, n=21)$. However, among the seven MenI ${ }^{+1-}$ male mice with adrenal cortical tumours, serum samples were available for analysis from only four mice; one of these was found to have a serum corticosterone that was markedly elevated at $655 \mathrm{nmol} / 1$ (i.e. $>10$ S.D. above the normal Men $1^{+/+}$male mean) while the other three had serum corticosterones of 52, 87 and $90 \mathrm{nmol} / \mathrm{l}$ which were in the normal range. The Men1 ${ }^{+/-}$male mouse with hypercorticosteronaemia and the adrenal cortical tumour did not have an anterior pituitary tumour, indicating that the hypercorticosteronaemia is not secondary to ACTH stimulation but instead due to the adrenal tumour. The mean serum corticosterone concentrations in the $\mathrm{Men1^{+/- }}$ female mice with adrenal hyperplasia $(70 \pm 17 \mathrm{nmol} / 1, n=10)$, Men $1^{+/-}$female mice without adrenal cortical abnormalities $(94 \pm 15 \mathrm{nmol} / \mathrm{l}, n=49)$, and Menl ${ }^{+/+}$ female mice $(81 \pm 25 \mathrm{nmol} / \mathrm{l}, n=19)$ were not significantly different. The finding of a hormone secreting adrenal tumour in 1 out of $4(\sim 25 \%)$ of the MenI ${ }^{+/-}$ male mice, is consistent with reports that such secreting adrenal tumours occur in 35\% of MEN1 patients (Calender et al. 1995, Trump et al. 1996, Marx et al. 1998, Vierimaa et al. 2007). However, corticosterone-producing adrenal tumours, in man, are usually carcinomas and cause sodium retention with a suppression of the renin-angiotensin system and decreased plasma aldosterone concentrations
(Edwards \& Stowasser 2006). The adrenal cortical tumour in the $\mathrm{Men} \mathrm{I}^{+/-}$male mouse with excess corticosterone did not have features of an adrenal carcinoma, and additional sera were not available to further study the effects of the corticosterone excess on glucocorticoid and mineralocorticoid homeostasis.

\section{Expression of $\mathrm{CgA}$, somatostatin receptor type 2, and vascular endothelial growth factor-A}

Pancreatic islet cell and pituitary tumours of MenI ${ }^{+/-}$ mice were investigated for expression of $\mathrm{CgA}$, somatostatin receptor type 2 (SSTR2) and vascular endothelial growth factor-A (VEGF-A). $\mathrm{CgA}$ was expressed abundantly in the pancreatic islet cell tumours of $\mathrm{Menl} \mathrm{I}^{+/-}$mice, but mainly on the periphery of pancreatic islets in $\mathrm{Menl}^{+/+}$mice (Fig. 5A). CgA expression also occurred abundantly in the anterior pituitary tumours of $\mathrm{Men1^{+/- }}$ mice, but sparsely in the anterior pituitaries of $\mathrm{Men1} \mathrm{I}^{+/+}$mice. The differences in $\mathrm{CgA}$ expression in the tumours did not correlate with serum CgA concentrations (Fig. 4D). SSTR2 expression occurred in the pancreatic islets and anterior pituitaries of $\mathrm{Men1^{+/+ }}$ mice as well as the pancreatic islet cell and anterior pituitary tumours of Men1 ${ }^{+/-}$mice (Fig. 5B), suggesting that these tumours may be amenable to treatment with somatostatin analogues. VEGF-A expression occurred abundantly in the pancreatic islets of $\mathrm{Menl}^{+/+}$mice and pancreatic islet cell tumours of $\mathrm{Menl} \mathrm{I}^{+/-}$mice (Fig. 5C). VEGF-A expression was also observed in the anterior pituitaries of $\mathrm{Men1^{+/+ }}$ mice and the anterior pituitary tumours of $\mathrm{Menl^{+/- }}$ mice (Fig. 5C). These results indicate that the pancreatic islet cell and anterior pituitary tumours of $\mathrm{MenI}^{+/-}$represent neuroendocrine tumours that express $\mathrm{CgA}$, that may be amenable to treatment with somatostatin analogues and inhibitors of angiogenesis, as they express SSTR2 and VEGF-A, respectively.

\section{Discussion}

The results of our study, which have established Menl ${ }^{+/-}$mice that are deleted for exons 1 and 2 , together with $>1.5 \mathrm{~kb}$ of the $5^{\prime}$ sequence that contains the UTR, promoter and alternative exons 1 , and $\sim 1 \mathrm{~kb}$ of the $3^{\prime}$ region of intron 2 of the Menl gene (Fig. 1), reveal that these $M e n 1^{+/-}$mice are representative of MEN1 in man. Thus, Men1 ${ }^{+/-}$mice develop parathyroid, pancreatic islet, anterior pituitary, adrenal cortical and lipomatous tumours (Figs 2 and 3). Moreover, the greater occurrence of anterior pituitary tumours in female $\mathrm{Men1^{+/- }}$ mice is similar to the 


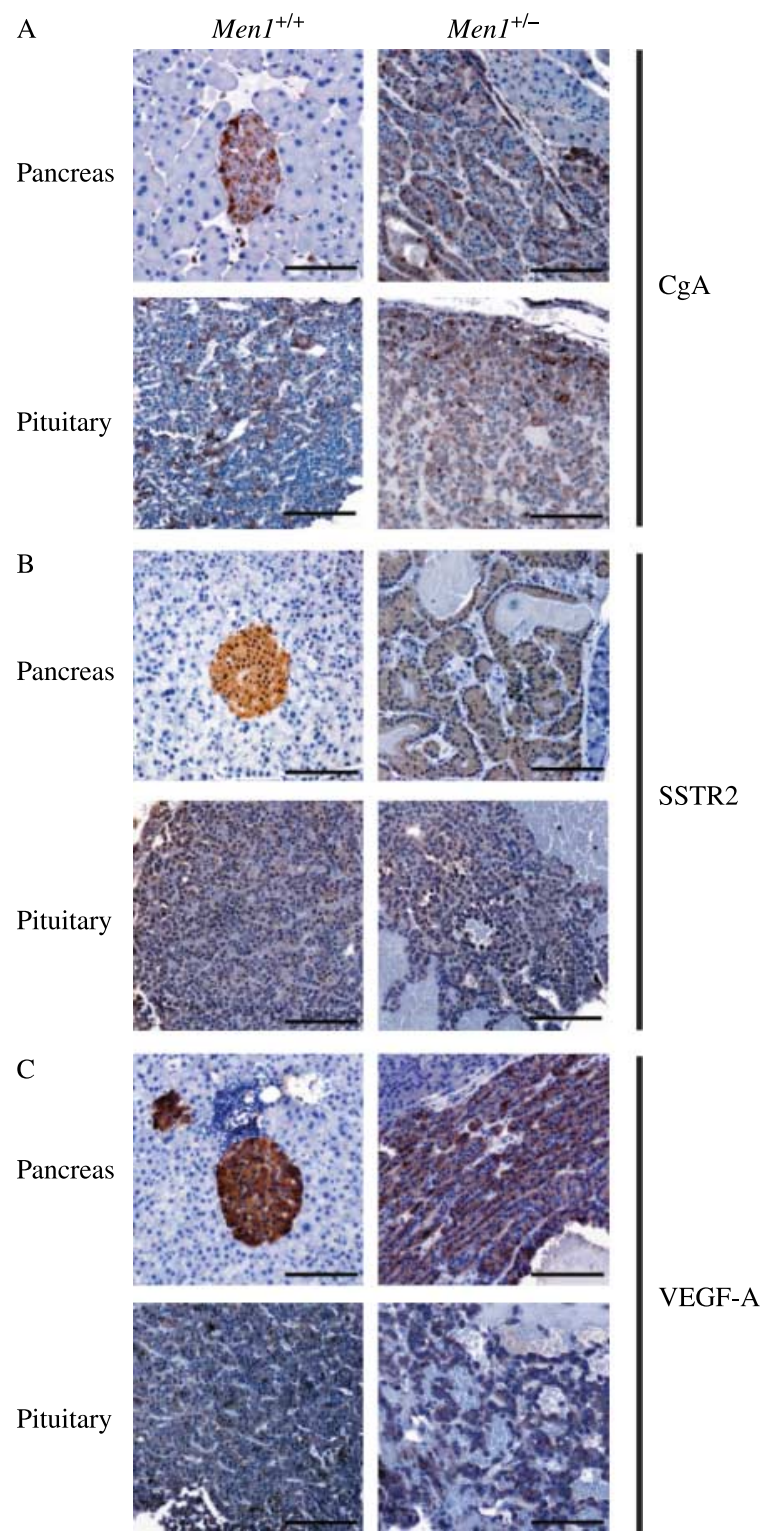

Figure 5 Immunohistochemistry revealing expression of chromogranin A $(\mathrm{CgA})$, somatostatin receptor type 2 (SSTR2), and vascular endothelial growth factor-A (VEGF-A) in pancreatic islets and anterior pituitary tumours of Men1 $1^{+/-}$ mice. (A) Chromogranin A was present in normal pancreatic islets and anterior pituitary cells of $M e n 1^{+/+}$mice, and in the pancreatic islet cell tumours and anterior pituitary tumours of $M e n 1^{+1-}$ mice. (B) Somatostatin receptor type 2 was present in Men $1^{+/+}$pancreatic islets and anterior pituitary, as well as pancreatic islet and anterior pituitary tumours of $M e n 1^{+/-}$mice; (C) VEGF-A expression was observed in Men $1^{+/+}$pancreatic islets and anterior pituitary as well as pancreatic islet cell tumours and anterior pituitary tumours of Men1 $1^{+/-}$mice.

gender difference observed in the occurrence of these tumours in MEN1 patients (Verges et al. 2002). The causes of this gender difference are not certain, and further studies of this MEN1 mouse model for gender-specific gene modifiers may help to elucidate these. Furthermore, the age-related onset of tumour development in the MenI ${ }^{+/-}$mice is similar to the age-related penetrance of MEN1 in man (Trump et al. 1996). Finally, LOH and a lack of menin expression was observed in the majority of the tumours from the Men1 ${ }^{+/-}$mice consistent with a tumour suppressor role for Men1, and similar to the findings reported in MEN1 tumours in man (Larsson et al. 1988, Lubensky et al. 1996). However, there are some interesting differences in the frequencies of tumours that develop in the $\mathrm{Men1} \mathrm{I}^{+/-}$mice and in patients with MEN1, and five of these are as follows: 1) parathyroid tumours are the commonest manifestation, occurring in $\sim 95 \%$, of MEN1 patients from $<10$ to $>75$ years (Benson et al. 1987, Calender et al. 1995, Trump et al. 1996, Marx et al. 1998), whereas they occurred in only $\sim 40 \%$ of Menl $^{+/-}$mice aged 3-21 months (Fig. 3), although amongst the $\geq 12$ months cohort they occurred in $>85 \%$ of $\mathrm{Menl}^{+/-}$mice, 2) gastrinomas are the commonest pancreatic islet cell tumours in MEN1 patients (Trump et al. 1996, Marx et al. 1998), whereas they did not occur in any of the Men1 ${ }^{+/-}$mice, 3) prolactinomas are the commonest anterior pituitary tumours in MEN1 patients (Trump et al. 1996, Marx et al. 1998, Verges et al. 2002), whereas somatolactotrophinomas are the commonest anterior pituitary tumour in the Menl ${ }^{+/-}$mice, 4) adrenal cortical tumours occurred only in Men ${ }^{+/-}$male mice, and this gender difference has not been reported to occur in man, and 5) gonadal tumours, which are rarely found in MEN1 patients, occurred commonly in Men1 $1^{+/-}$ mice. The basis of these inter-species differences remain to be defined but they may partly be due to: the methods of detection used, e.g. autopsy in the mice which may identify more tumours as opposed to biochemical and radiological investigations in man; the effects of species-specific genetic modifiers that might alter the phenotypic expression of the Menl mutation in a species; and the absence of a particular lineage, e.g. gastrin producing cells, in the pancreatic islets of $M e n 1^{+1-}$ mice and hence the absence of gastrinomas in these mice.

The Men1 ${ }^{+/-}$mice described in this report develop tumours that are similar to those reported in other conventional MEN1 mouse models (Table 1; Crabtree et al. 2001, Bertolino et al. 2003a, Loffler et al. 2007). Thus, all the Menl ${ }^{+/-}$mice develop parathyroid, pancreatic islet cell, anterior pituitary, adrenal cortical and gonadal tumours. However, there are important differences that follow. First, gastrinomas which were extrapancreatic were reported in only one MEN1 model (Bertolino et al. 2003a). Second, gastric 
neuroendocrine tumours were reported in only one other model (Crabtree et al. 2001). Third, invasive carcinomas were reported in one model (Bertolino et al. 2003a), but not in the other two models (Crabtree et al. 2001, Loffler et al. 2007) or this MEN1 mouse model. The reasons underlying these differences in observed phenotype are not clear, but may be strain dependent or due to differences in the extent to which regional lymph nodes and lungs were sampled to detect carcinomas and metastases. Fourth, the occurrence of hypercalcaemia (Fig. 4A) and hypophosphataemia (Fig. 4B) in association with parathyroid hyperplasia and adenomas were observed only in the Men1 ${ }^{+/-}$ mice of this report. The hypercalcaemia was associated with inappropriately normal serum PTH concentrations for the prevailing $\mathrm{ACa}$ in these $\mathrm{Men1^{+/- }}$ mice with parathyroid abnormalities (Fig. 4C); this is consistent with primary hyperparathyroidism (Eastell et al. 2009). Moreover, the finding of hypercalcaemia in association with hypophosphataemia is consistent with the presence of elevations in biologically active PTH concentrations. The absence of hypercalcaemia in the other MEN1 models (Table 1) is difficult to reconcile, and possible explanations may be the different responses of the mouse strains, the calcium and vitamin $\mathrm{D}$ content of the diets, or the method used to measure the serum calcium. Conditional and specific deletion of both of the Menl alleles in the parathyroids results in hypercalcaemia and parathyroid tumours (Libutti et al. 2003), in agreement with our observations (Table 1 ).

To further investigate the possible utility of the established MEN1 model for treatments, we investigated the $\mathrm{Menl} \mathrm{I}^{+/-}$mice for alterations in serum $\mathrm{CgA}$ (Fig. 4D) and for tumour expression of CgA, SSTR2 and VEGF-A (Fig. 5). Pancreatic islet cell and pituitary tumours represent neuroendocrine tumours that are highly vascularised, and previous studies in man, have reported that these tumours, as assessed by immunohistochemistry, express CgA, SSTR2 and VEGF-A (Moller et al. 2003, Turner et al. 2003, Helle et al. 2007). In addition, serum $\mathrm{CgA}$ has been reported to correlate with pancreatic neuroendocrine tumour burden in MEN1 patients (Janson et al. 1997, Granberg et al. 1999) although the variation in serum CgA can be marked due to tumour instability and liability to release hormones (Granberg et al. 1999). The pancreatic islet and anterior pituitary tumours in the $\mathrm{Men} \mathrm{I}^{+/-}$mice were found to contain $\mathrm{CgA}$ (Fig. 5A), but serum $\mathrm{CgA}$ was not found to be elevated in these mice (Fig. 4D), indicating that $\mathrm{CgA}$ may not be easily released from these tumour cells and that serum $\mathrm{CgA}$ is unlikely to be a useful marker for monitoring response to treatments in these Menl ${ }^{+/-}$mice. However, the finding of $\mathrm{CgA}$ expression within the $\mathrm{MenI} \mathrm{I}^{+/-}$mice anterior pituitary tumours that also contain prolactin, is unusual, as in man it has been reported that prolactinomas, in contrast to all other pituitary adenomas, do not express $\mathrm{CgA}$ (Lloyd et al. 1989). Moreover, normal endocrine cells of the pituitary, in man, usually express $\mathrm{CgA}$, and the observation of abundant $\mathrm{CgA}$ expression in the prolactin containing anterior pituitary tumour cells of $\mathrm{MenI}^{+/-}$mice implies that $\mathrm{CgA}$ expression may be upregulated upon neoplastic transformation. In order to facilitate investigation of future therapies for the tumours in $\mathrm{Men1^{+/- }}$ mice, we investigated them for SSTR2 (Fig. 5B) and VEGF-A (Fig. 5C) expression. The expression of SSTR2 and VEGF-A by the pancreatic islet and anterior pituitary tumours of these $\mathrm{MenI} \mathrm{I}^{+/-}$mice, indicates that they are likely to respond to treatment with somatostatin analogues and inhibitors, e.g. monoclonal antibodies, of angiogenesis, respectively.

In summary, we have established a Men1 ${ }^{+/-}$mouse model that is representative of MEN1 in man, and our demonstration of SSTR2 and VEGF-A expression in the pancreatic islet cell tumours and anterior pituitary tumours, indicates that these $\mathrm{Men1^{+/- }}$ mice will be of use in evaluating therapies with established and emerging somatostatin analogues, and inhibitors of angiogenesis.

\section{Declaration of interest}

The authors declare that there is no conflict of interest that could be perceived as prejudicing the impartiality of the research reported in this article.

\section{Funding}

This work was supported by the Medical Research Council (G9825289, 2004), UK (B Harding, M C Lemos, A A C Reed, M R Bowl, G V Walls, J Jeyabalan, H Tateossian, $\mathrm{T}$ Hough, M T Cheeseman and R V Thakker), and the Portuguese Foundation for Science and Technology (BD/12415/2003) (M C Lemos).

\section{Acknowledgements}

We are grateful to T Hacker and J Humphreys (MRC Mary Lyon Centre, Harwell) for assistance in preparation of histology sections, S Thomas (MRC, Mary Lyon Centre, Harwell) for preparing Fig. 2, Prof I Mason, Reproductive and Developmental Sciences, University of Edinburgh, for the gift of the anti-3 $\beta$-HSD antibody, Dr A F Parlow, National Institute of Diabetes and Digestive and Kidney Diseases, Torrance, CA, USA for the anti-prolactin antibody and to Mrs Tracey Walker for typing the manuscript. 


\section{References}

Benson L, Ljunghall S, Akerstrom G \& Oberg K 1987 Hyperparathyroidism presenting as the first lesion in multiple endocrine neoplasia type 1. American Journal of Medicine 82 731-737.

Bertolino P, Tong WM, Galendo D, Wang ZQ \& Zhang CX $2003 a$ Heterozygous Men1 mutant mice develop a range of endocrine tumors mimicking multiple endocrine neoplasia type 1. Molecular Endocrinology 17 1880-1892.

Bertolino P, Tong WM, Herrera PL, Casse H, Zhang CX \& Wang ZQ 2003b Pancreatic beta-cell-specific ablation of the multiple endocrine neoplasia type 1 (MEN1) gene causes full penetrance of insulinoma development in mice. Cancer Research 63 4836-4841.

Biondi CA, Gartside MG, Waring P, Loffler KA, Stark MS, Magnuson MA, Kay GF \& Hayward NK 2004 Conditional inactivation of the MEN1 gene leads to pancreatic and pituitary tumorigenesis but does not affect normal development of these tissues. Molecular and Cellular Biology 24 3125-3131.

Calender A, Giraud S, Cougard P, Chanson P, Lenoir G, Murat A, Hamon P \& Proye C 1995 Multiple endocrine neoplasia type 1 in France: clinical and genetic studies. Journal of Internal Medicine 238 263-268.

Capen CC, Gröne A, Bucci TJ \& Rosol TJ 1996 Changes in structure and function of the parathyroid gland. In Pathobiology of the Aging Mouse, pp 109-123. Eds U Mohru, DL Dungworth, CC Capen, WW Carlton, JP Sundberg \& JM Ward. Washington DC: International Life Sciences Institute Press.

Chandrasekharappa SC \& Teh BT 2003 Functional studies of the MEN1 gene. Journal of Internal Medicine $\mathbf{2 5 3}$ 606-615.

Chandrasekharappa SC, Guru SC, Manickam P, Olufemi SE, Collins FS, Emmert-Buck MR, Debelenko LV, Zhuang Z, Lubensky IA, Liotta LA et al. 1997 Positional cloning of the gene for multiple endocrine neoplasia-type 1. Science 276 404-407.

Chang W, Tu C, Chen TH, Bikle D \& Shoback D 2008 The extracellular calcium-sensing receptor (CaSR) is a critical modulator of skeletal development. Science Signaling 1 ra1.

Crabtree JS, Scacheri PC, Ward JM, Garrett-Beal L, Emmert-Buck MR, Edgemon KA, Lorang D, Libutti SK, Chandrasekharappa SC, Marx SJ et al. 2001 A mouse model of multiple endocrine neoplasia, type 1, develops multiple endocrine tumors. PNAS 98 1118-1123.

Crabtree JS, Scacheri PC, Ward JM, McNally SR, Swain GP, Montagna C, Hager JH, Hanahan D, Edlund H, Magnuson MA et al. 2003 Of mice and MEN1: insulinomas in a conditional mouse knockout. Molecular and Cellular Biology 23 6075-6085.

Eastell R, Arnold A, Brandi ML, Brown EM, D'Amour P, Hanley DA, Rao DS, Rubin MR, Goltzman D, Silverberg SJ et al. 2009 Diagnosis of asymptomatic primary hyperparathyroidism: proceedings of the third international workshop. Journal of Clinical Endocrinology and Metabolism 94 340-350.

Edwards CRW \& Stowasser M 2006 Primary mineralocorticoid excess syndromes. In Endocrinology, edn 5, pp 2461-2490. Eds LJ DeGroot \& JL Jameson. Philadelphia: Elsevier Saunders.

Gibril F, Schumann M, Pace A \& Jensen RT 2004 Multiple endocrine neoplasia type 1 and Zollinger-Ellison syndrome: a prospective study of 107 cases and comparison with 1009 cases from the literature. Medicine 83 43-83.

Granberg D, Stridsberg M, Seensalu R, Eriksson B, Lundqvist G, Oberg K \& Skogseid B 1999 Plasma chromogranin A in patients with multiple endocrine neoplasia type 1. Journal of Clinical Endocrinology and Metabolism 84 2712-2717.

Helle KB, Corti A, Metz-Boutigue MH \& Tota B 2007 The endocrine role for chromogranin A: a prohormone for peptides with regulatory properties. Cellular and Molecular Life Sciences 64 2863-2886.

Hough TA, Nolan PM, Tsipouri V, Toye AA, Gray IC, Goldsworthy M, Moir L, Cox RD, Clements S, Glenister PH et al. 2002 Novel phenotypes identified by plasma biochemical screening in the mouse. Mammalian Genome 13 595-602.

Janson ET, Holmberg L, Stridsberg M, Eriksson B, Theodorsson E, Wilander E \& Oberg K 1997 Carcinoid tumors: analysis of prognostic factors and survival in 301 patients from a referral center. Annals of Oncology $\mathbf{8}$ 685-690.

Khodaei-O'Brien S, Zablewska B, Fromaget M, Bylund L, Weber G \& Gaudray P 2000 Heterogeneity at the 5'-end of MEN1 transcripts. Biochemical and Biophysical Research Communications 276 508-514.

Larsson C, Skogseid B, Oberg K, Nakamura Y \& Nordenskjold M 1988 Multiple endocrine neoplasia type 1 gene maps to chromosome 11 and is lost in insulinoma. Nature 332 85-87.

Lemos MC \& Thakker RV 2008 Multiple endocrine neoplasia type 1 (MEN1): analysis of 1336 mutations reported in the first decade following identification of the gene. Human Mutation 29 22-32.

Lemos MC, Harding B \& Thakker RV 2007 Genetic background influences expression of multiple endocrine neoplasia type 1 (MEN1) mutation, implicating a role for genetic modifiers. Endocrine Abstracts 13 P19.

Libutti SK, Crabtree JS, Lorang D, Burns AL, Mazzanti C, Hewitt SM, O'Connor S, Ward JM, Emmert-Buck MR, Remaley A et al. 2003 Parathyroid gland-specific deletion of the mouse Men1 gene results in parathyroid neoplasia and hypercalcemic hyperparathyroidism. Cancer Research 63 8022-8028.

Lloyd RV, Iacangelo A, Eiden LE, Cano M, Jin L \& Grimes M 1989 Chromogranin A and B messenger ribonucleic acids in pituitary and other normal and neoplastic human endocrine tissues. Laboratory Investigation 60 548-556. 
Loffler KA, Biondi CA, Gartside M, Waring P, Stark M, Serewko-Auret MM, Muller HK, Hayward NK \& Kay GF 2007 Broad tumor spectrum in a mouse model of multiple endocrine neoplasia type 1. International Journal of Cancer 120 259-267.

Lubensky IA, Debelenko LV, Zhuang Z, Emmert-Buck MR, Dong Q, Chandrasekharappa S, Guru SC, Manickam P, Olufemi SE, Marx SJ et al. 1996 Allelic deletions on chromosome 11q13 in multiple tumors from individual MEN1 patients. Cancer Research 56 5272-5278.

Malisch JL, Kelly SA, Bhanvadia A, Blank KM, Marsik RL, Platzer EG \& Garland T 2009 Lines of mice with chronically elevated baseline corticosterone levels are more susceptible to a parasitic nematode infection. Zoology 112 316-324.

Marx SJ 2005 Molecular genetics of multiple endocrine neoplasia types 1 and 2. Nature Reviews. Cancer 5 367-375.

Marx S, Spiegel AM, Skarulis MC, Doppman JL, Collins FS \& Liotta LA 1998 Multiple endocrine neoplasia type 1: clinical and genetic topics. Annals of Internal Medicine 129 484-494.

Moller LN, Stidsen CE, Hartmann B \& Holst JJ 2003 Somatostatin receptors. Biochimica et Biophysica Acta 1616 1-84.

Nesbit MA, Bowl MR, Harding B, Ali A, Ayala A, Crowe C, Dobbie A, Hampson G, Holdaway I, Levine MA et al. 2004 Characterization of GATA3 mutations in the hypoparathyroidism, deafness, and renal dysplasia (HDR) syndrome. Journal of Biological Chemistry 279 22624-22634.

Nyska A \& Maronpot RR 1999 Pathology of the Mouse. Vienna, IL, USA: Cache River Press.

Pannett AA \& Thakker RV 2001 Somatic mutations in MEN type 1 tumors, consistent with the Knudson "two-hit" hypothesis. Journal of Clinical Endocrinology and Metabolism 86 4371-4374.
Scacheri PC, Crabtree JS, Novotny EA, Garrett-Beal L, Chen A, Edgemon KA, Marx SJ, Spiegel AM, Chandrasekharappa SC \& Collins FS 2001 Bidirectional transcriptional activity of PGK-neomycin and unexpected embryonic lethality in heterozygote chimeric knockout mice. Genesis 30 259-263.

Thakker RV 2006 Multiple endocrine neoplasia type 1. In Endocrinology, edn 5, pp 3509-3531. Eds LJ DeGroot \& JL Jameson. Philadelphia: Elsevier Saunders.

Thakker RV, Bouloux P, Wooding C, Chotai K, Broad PM, Spurr NK, Besser GM \& O'Riordan JL 1989 Association of parathyroid tumors in multiple endocrine neoplasia type 1 with loss of alleles on chromosome 11. New England Journal of Medicine 321 218-224.

The European Consortium on MEN1 1997 Identification of the multiple endocrine neoplasia type 1 (MEN1) gene. The European Consortium on MEN1. Human Molecular Genetics 6 1177-1183.

Trump D, Farren B, Wooding C, Pang JT, Besser GM, Buchanan KD, Edwards CR, Heath DA, Jackson CE, Jansen S et al. 1996 Clinical studies of multiple endocrine neoplasia type 1 (MEN1). Quarterly Journal of Medicine 89 653-669.

Turner HE, Harris AL, Melmed S \& Wass JA 2003 Angiogenesis in endocrine tumors. Endocrine Reviews 24 600-632.

Verges B, Boureille F, Goudet P, Murat A, Beckers A, Sassolas G, Cougard P, Chambe B, Montvernay C \& Calender A 2002 Pituitary disease in MEN type 1 (MEN1): data from the France-Belgium MEN1 multicenter study. Journal of Clinical Endocrinology and Metabolism 87 457-465.

Vierimaa O, Ebeling TM, Kytola S, Bloigu R, Eloranta E, Salmi J, Korpi-Hyovalti E, Niskanen L, Orvola A, Elovaara E et al. 2007 Multiple endocrine neoplasia type 1 in Northern Finland; clinical features and genotype phenotype correlation. European Journal of Endocrinology 157 285-294. 